\title{
Phenotypic Characterization of Marwari Goats under Field Conditions
}

\author{
Hemlata Chouhan $^{1 *}$, Gyan Chand Gahlot ${ }^{1}$, Vijay Kumar Agrawal ${ }^{2}$ and Sunita Meena ${ }^{3}$ \\ ${ }^{1}$ Department of Animal Breeding \& Genetics, Veterinary College, Bikaner, Rajasthan, India \\ ${ }^{2}$ Department of Animal Husbandry, Rajasthan, India \\ ${ }^{3}$ Teaching Associate, Department of Animal Breeding \& Genetics, Veterinary College, \\ Navania, Rajasthan, India \\ *Corresponding author
}

\section{A B S T R A C T}

The phenotypic characterization of Marwari goats under field condition in the Arid Region of Rajasthan was carried in the present study. The detailed information of all animals $(\mathrm{n}=36,566)$ on morphological traits at birth, 3, 6, 9, 12, 18,24 months and adult age was

\section{Keywords}

Colour, Body measurement, Marwari goat

\section{Article Info}

Accepted:

18 May 2020

Available Online:

10 June 2020 collected from farmer's flock under field condition born during 1990 to 2015 to analyze the effect of coat colour on body weight of Marwari goats in relation to heat adaptability. The data pertaining to various morphological traits and body measurements were analyzed by IBM SPPS software to study the colour of body coat, muzzle colour, ear colour, beard, wattles and correlation between body measurements. The predominant colour seen in all the animals was black followed by an admixture of black, brown and white. In present study estimated that out of total animals 10 per cent of animals were having beard and 9.4 per cent animals having wattles. Beard and wattles are present in both sexes. Mean and standard deviation of body measurements of Marwari goats were observed to be height $60.72 \pm 0.24(\mathrm{~cm})$, length $52.54 \pm 0.20(\mathrm{~cm})$, heart girth $66.42 \pm 0.21(\mathrm{~cm})$, ear length $16.01 \pm 0.06 \mathrm{~cm}$, horn length $7.57 \pm 0.04 \mathrm{~cm}$. Correlation between height and length 0.830 , height and heart girth 0.0856, height and ear length 0.632, height and horn length 0.568 , height and coat colour 0.116 , length and heart girth 0.773 , length and ear length 0.584 , length and horn length 0.579 . length and coat colour 0.102 , heat girth and ear length 0.639 , heart girth and horn length 0.554 , heart girth and coat colour 0.089 , ear length and horn length 0.489 , ear length and coat colour 0.113 , horn length and coat colour 0.077 . The effect of coat colour were estimated as highly significant $(\mathrm{P} \leq 0.01)$ on all ages group animals.

\section{Introduction}

India is a rich repository of goat genetic resources in the form of 34 well defined breeds (Anonymous, 2018). India ranks second in world in terms of goat population which is around 135.17 million. Rajasthan accounts for about $16.03 \%$ (21.66 million)of total goat population of Indian subcontinent. The state ranks first in goat population with having major goat breed such Marwari, Sirohi, Jhakrana and Barbari. The state has witnessed an increase of $0.76 \%$ in goat population (Anonymous, 2012) despite a 
downward trend $(3.82 \%)$ in national goat population. The Marwari goat is the second most populous goat breed in India which constitutes about $5.31 \%$ ( 7.18 million) of the total goat population of India with pure bred animal of about 5.34 million $\left(19^{\text {th }}\right.$ Livestock Census 2012). Growth traits are also important indicators of adaptability of the species in relation to its environmental conditions.

The Marwari goat breed of Rajasthan is a dual purpose animal that is known for its faster growth, efficient breeding, high salt tolerance and requires less water than any other species of the region (Shankarnarayan et al., 1985; Rohila and Patel, 2003). The Marwari goat is the second most populous goat breed in India which constitutes about $5.31 \%$ (7.18 million) of the total goat population of India with pure bred animal of about 5.34 million (19 ${ }^{\text {th }}$ Livestock Census, 2012). The Marwari goat breeding tract extends from the region of Jaisalmer, Barmer, Jalore, Pali, Jodhpur, Nagaur to Bikaner district. The individuals of Marwari goat are predominantly black in color with small head and thin tail. The udder is fairly well developed with small and round teat placed laterally. The male bears thick beard. The ears are small and flat. Both sexes have short pointed horns, directed upward and backward (NBAGR, 2016). The amount of radiant heat absorbed by the animal's coat is partly determined by colour, length and condition of its hair. Light from the invisible infra-red part of solar radiation is completely absorbed irrespective of coat colour, but thevisible portion of radiation is absorbed by the animals coat depending upon its colour. Studies have confirmed that dark coats absorb more solar radiation than light coats (Cena, 1966. Penetration of fur by solar beams is a function not only of the colour but also of the structure of the coat (Hutchinson and Brown, 1969).

Thus, it is likely that coat structure and colour may influence the heat tolerance of animals in hot climate. In the present study, an attempt was made to study of phenotypic characters and their correlation with each other.

\section{Materials and Methods}

The data for the present investigation was collected from flocks of Marwari goat maintained under ICAR sponsored “All India Co-ordinated Research Project (AICRP) on goat improvement," Bikaner, Rajasthan. The information on different morphological measurements of Marwari goat were collected for the period from 1990 to 2015 from the different cluster villages, Deshnoke, Udairamsar, Kalyansar, Nokha, Raiser, Diaya and Moondsar cluster of Bikaner district. The geographical location of Bikaner district is located geographically in latitude $27^{\circ} 11^{\prime}$ $29^{\circ} 3^{\prime} \mathrm{N}$ and longitude $71^{\circ} 54^{\prime}-74^{\circ} 12^{\prime}$ E. Bikaner district is situated at height of 238 meters above sea level. The region is characterized by extreme temperatures as high as $49^{\circ} \mathrm{C}$ during summer and as low as $0^{\circ} \mathrm{C}$ during winters. The region receives an annual precipitation of $260 \mathrm{~mm}$ which is mostly erratic in nature. The Marwari goat flocks in the above said cluster were maintained under field condition. Physical description of a breed should focus on characters, which in the view of keepers of the breed and local experts facilitate identification of animals as being members of the breed or strain. These should include coat color (common and/or special colors and color combinations); muzzle colour and ear colour other specific visible characteristics. As we know our livestock in general, small ruminants in particular are multi-purpose. In addition their adaptability capacity to the wide range of agro ecological condition makes them to utilize under extensive farming system. But as it is clear, to utilize them effectively; characterization to the breed level or to the type level is very important. The information for various Coat colour, muzzle colour, ear colour, beard, 
wattles and body measurements were recorded regularly by the technical staff of the project. Qualitative traits like the body coat colour, muzzle colour, presence and absence of beard and wattles evaluated and recorded on the basis of visual observation. Various measurable phenotypic characters were recorded individually from the randomly selected goats in the study area. The linear body measurements like height, length, heart girth and horn length were recorded using simple measuring tape and body weight was recorded using the spring balance by hanging the animals in weighing bag designed for the purpose.

Ear length : Distance from the base of ear to the tip of the ear

Horn length : Distance from the base of the horn to tip of the horn

Height : height at withers vertical distance from ground to the highest point of wither

Length : length from the point of the shoulder to the pin bone

Heart girth : circumference of the chest just behind the point of elbow

\section{Statistical analysis}

The data pertaining to various morphological traits and body measurements were analyzed by IBM SPPS software to study the colours of body coat, muzzle colour ear colour, beard, wattles and correlation between body measurements. Qualitative traits like the body coat colour, muzzle colour, presence and absence of beard and wattles evaluated and recorded on the basis of visual observation. Pearson correlation coefficients were calculated for all the body measures (body weight, height and length). Further, correlation of body weight was calculated with various linear measures of different age groups (0-3 months, 3-6 months, 6-9 months and more than 12 months) of goats. The correlation is the measure of the degree of association between the observed values of the two traits. Correlation will be estimated by using the following formula:

$$
\mathbf{r}_{(\mathrm{XY})}=\frac{\operatorname{Cov}(\mathrm{XY})}{\sqrt{ } \boldsymbol{\sigma}^{2}(\mathrm{X}) * \sigma^{2}(\mathrm{Y})}
$$

where,

Cov $(X Y)=$ covariance between trait $X$ and $Y$ $\sigma^{2}(X)$ and $\sigma^{2}(Y)=$ phenotypic variance of trait $\mathrm{X}$ and $\mathrm{Y}$

The standard error of phenotypic correlations can be calculated as:

$$
\mathrm{SE}(\mathrm{r})=\sqrt{ }\left[1-\mathrm{r}^{2}(\mathrm{XY})\right] / \sqrt{ }[\mathrm{N}-2]
$$

where,

$\mathrm{r}_{(\mathrm{XY})}=$ correlation between trait $\mathrm{X}$ and $\mathrm{Y}, \mathrm{N}$ $2=$ Degree of freedom

\section{Results and Discussion}

\section{Body coat colour}

All the six described colours were found in almost all the animals of the seven clusters and all age groups given in Table 1,2 and Fig.1. The predominant colours seen in all the animals of the seven cluster and all age groups were black followed by an admixture of black, brown and white. In present study estimated that out of total animals 10 per cent of animals were having beard and 9.4 per cent animals having wattles. Marwari body coat colour also has close similarity with report of Vermaet al.(2010) for Sangamneri goat in which black, brown, white \& admixture of two colours body coat colour present. The present study has close similarity with report of Verma et al.(2015) in Ganjam goat in which observed black, brown, blackish brown, brownish black sometimes with white patches body coat colour, Mandakmale et al. (2016) in Kathewadi goat observed black, Black with white patches, Brownish black, Brown. Present study differs from reports of 
Deokaret al.(2007) having white coat colour in Sangamneri goat, Deshapandeet al.(2009) having white coat in Surti goat. Body Coat color is the simplest characteristic to look for when identifying the breed of a goat population since it is easily and quickly observed. Coat color of an animal could be plain (i.e. only one color) or patchy (i.e. patches of different colors on a major background color such as a black or white with other color patches).

The Indian breeds of goats known for wide variations such as body coat colour reported in literature, viz., light to dark brown coat colour of Sirohi goats (Pathodiya et al., 2004), pure black, white, and brown colours of Bengal goats (Tudu et al., 2016), black, fawn and white of Chaugarkha goat breed of Uttaranchal (Singh and Barwal,2007), black colour in most of theZalawadi goats(Singh et al., 2007), yellowish brown colour of PallaiAdu breed (Ravimurugan et al., 2009), uniformly black colour covered with long coarse hair of Gohilwadi goats (Singh et al., 2009), mostly white and black or white and brown of Malabari goats of Kerala (Verma et al., 2009), white coat colour of Jamunapari goats (Rout et al., 2002), black or brown coat with white markings on collar of KonkanKanyal goats (Verma et al., 2012)

\section{Muzzle colour and ear colour}

In present study on all the animals of the seven cluster and all age groups of Marwari goat muzzle colour seen predominant black followed by an admixture of black, brown and white. Out of total animals more than 90 per cent of the animals in all age groups were having black muzzle colour. Ear colour of Marwari goat observed predominant black followed by an admixture of black, brown and white of ear color which is close similar with Verma et al. (2015) in Ganjam goat which having black, brown, blackish brown, brownish black sometimes with white patches. In Malabari goat complete white, admixtures of white and brown, black and brown to complete black ear colour present (Verma et al., 2009) this is also similar with Marwari goat. Sangamneri goat had white ear colour (Deokar et al., 2007) which is different from present study on Marwari goat but similar report found by Vermaet al.(2010) black, brown, white \& admixture of them in Sangamneri goat. However, different results was reported as white brown colour of PallaiAdu breed (Ravimurugan et al., 2009), pink and black of Surti goats (Deshapande et al., 2009), as pinkish red muzzle of KonkanKanyal goat (Verma et al., 2012).

\section{Beard and wattles}

In present study estimated that out of total animals 10 per cent of animals were having beard and 9.4 per cent animals having wattles. Wattles present in Marwari goat in percentage at birth, 3, 6, 9, 12, 18, 24 months and adults were $0.10,2.10,2.40,5.40,17.90,19.80$, 20.10 , and 20.60 respectively. Beard present in Marwari goat in percentage at birth, 3, 6, 9, 12, 18, 24 months and adults were $0.10,1.70$, $2.70,3.70,17.90,20.90,23.40$ and 28.00 respectively given in Table 3 . This study has close similarity with Sangamneri goat (Verma et al., 2010) which had $10 \%$ beard. In Malabari goat 20\% animals had beard (Verma et al., 2009) which has higher value then Marwari goat. While in Surti goat $4 \%$ had beard and $7.33 \%$ had wattles (Deshapande et al., 2010), in KonkanKanyal goat Wattles absent, beard was rarely present (Verma et al., 2012). While some workers found differ from present study, viz., Deokaret al. (2007) reported absence of beard and wattles in Sangamneri goat and Vermaet al.(2012) reported absence of wattles in KonkanKanyal goat.

The highest percentage of wattles were observed in White (9\%) followed by Brown $(8.67 \%)$ and Black (8.40) colour varieties of Bengal goats. The highest percentage of beard 
were observed in Black $(6.80 \%)$ followed by Brown $(6 \%)$ and White $(6 \%)$ Bengal goats (Tudu et al., 2016), 10 per cent of Sangamneri in Maharashtra animals (male and females) had beard with only two per cent showing wattles (Verma et al., 2010), Surti goats were bearded (4\%) and non-bearded (96\%), Beard and wattles are seen both in male and female of Ganjam goats (Verma et al., 2015).

\section{Body measurements}

\section{Height}

In present study reported height $60.72 \pm 0.24$ (cm ) of Marwari goat The overall body height at 12 months body height of goats reported in literature as $60.28 \pm 0.30 \mathrm{~cm}$ in Ganjam goats (Patro and Mishra, 1987), 67.19 $\pm 0.71 \mathrm{~cm}$ in KanniAdu goats (Thiruvenkadan et al., 2000), $62.50 \mathrm{~cm}$ in Barbari goats (Singh and Rout, 2001), $61.92 \pm 0.26 \mathrm{~cm}$ in Sirohi goats (Pathodiya et al., 2004), $60.06 \pm$ $0.56 \mathrm{~cm}$ in Barberi goats (Kharkar et al., 2014).

\section{Body length}

Body length observed as 52.54 $\pm 0.20(\mathrm{~cm})$ for Marwari goat. At 12 months, body length of goats reported in literature $52.32 \pm 0.29 \mathrm{~cm}$ in Ganjam goats (Patro and Mishra, 1987), 59.16 $\pm 0.62 \mathrm{~cm}$ in Kanni Adu goats (Thiruvenkadan et al., 2000), $62.00 \mathrm{~cm}$ in Barbari goats (Singh and Rout, 2001), $58.09 \pm$ $0.29 \mathrm{~cm}$ in Sirohi goats (Pathodiya et al.,
2004), $57.04 \pm 0.56 \mathrm{~cm}$ in Berari goats (Kharkar et al., 2014).

\section{Heart girth}

Hear girth was observed to be $66.42 \pm$ $0.21(\mathrm{~cm})$. The 12 months heart girth of goats reported in literature as $56.36 \pm 0.27 \mathrm{~cm}$ in Ganjam goats (Patro and Mishra, 1987), 60.44 $\pm 0.64 \mathrm{~cm}$ in KanniAdu goats (Thiruvenkadan et al., 2000), $62.53 \mathrm{~cm}$ in Barbari goats (Singh and Rout, 2001), $64.07 \pm 0.25 \mathrm{~cm}$ in Sirohi goats (Pathodiya et al., 2004), $64.35 \pm$ $0.49 \mathrm{~cm}$ in goats (Kharkar et al., 2014).

\section{Horn length}

The presence or absence of horns also differentiates breeds of goats. Furthermore, the size and shape of horns differ in different breeds. Horn length was observed to be $7.57 \pm 0.04 \mathrm{~cm}$ in Marwari goats. The horn length of goats reported in literature as $6.80 \pm 0.22 \mathrm{~cm}$ for Chaugarkha goats (Singh and Barwal 2007), $11.84 \pm 0.68 \mathrm{~cm}$ for Malabari goats (Verma et al., 2009), $11.96 \pm$ 0.02 for Pallaiadu goats (Ravimurugan et al., 2009), 12.12 \pm 0.50 for Sangamneri goats (Verma et al., 2010), 13.04 \pm 0.32 for Konkan Kanyal goats (Verma et al., 2012), 13.73 \pm 1.29 for Surti goats (Dixit et al., 2013), up to 53 for Ganjam goats (Verma et al., 2015).

Table.1 Overall body morphological traits/ colour of Marwari goat

\begin{tabular}{|l|l|l|l|}
\hline $\begin{array}{l}\text { Traits/ } \\
\text { Colour }\end{array}$ & $\begin{array}{l}\text { Body coat } \\
(\%)\end{array}$ & $\begin{array}{l}\text { Ear colour } \\
(\boldsymbol{\%})\end{array}$ & $\begin{array}{l}\text { Muzzle colour } \\
(\boldsymbol{\%})\end{array}$ \\
\hline 1.B & 93.40 & 93.90 & 93.40 \\
\hline 2.B-BR & 1.80 & 0.20 & 0.30 \\
\hline 3. BR & 1.00 & 4.20 & 4.20 \\
\hline 4. BR-W & 0.10 & 0.10 & 0.20 \\
\hline 5. B-W & 3.10 & 0.40 & 0.60 \\
\hline 6. W & 0.50 & 1.10 & 1.30 \\
\hline
\end{tabular}

Note: $-\mathrm{B}=$ black, $\mathrm{BR}=$ brown, $\mathrm{W}=$ white, $\mathrm{B}-\mathrm{BR}=$ =black-brown, $\mathrm{B}-\mathrm{W}=$ black-white, $\mathrm{BR}-\mathrm{W}=$ brown-white colour. 
Table.2 Body morphological traits of Marwari goat according to age groups

\begin{tabular}{|c|c|c|c|c|}
\hline $\begin{array}{l}\text { Traits/ } \\
\text { age group }\end{array}$ & Colour & $\begin{array}{l}\text { Body coat } \\
(\%)\end{array}$ & $\begin{array}{l}\text { Ear colour } \\
(\%)\end{array}$ & $\begin{array}{l}\text { Muzzle colour } \\
(\%)\end{array}$ \\
\hline \multirow[t]{4}{*}{ Birth } & $\mathrm{B}$ & 98.90 & 99.80 & 99.80 \\
\hline & B-BR & 0.40 & - & - \\
\hline & $\mathrm{B}-\mathrm{W}$ & 0.50 & - & - \\
\hline & $\mathrm{Br}$ & 0.20 & 0.10 & 0.10 \\
\hline \multirow[t]{6}{*}{$3 \mathbf{m}$} & B & 98.40 & 97.10 & 97.00 \\
\hline & B-BR & 0.30 & 0.00 & 0.00 \\
\hline & B-W & 0.90 & 0.20 & 0.40 \\
\hline & $\mathrm{BR}$ & 0.00 & 2.30 & 2.30 \\
\hline & BR-W & 0.30 & 0.10 & 0.10 \\
\hline & $\mathrm{W}$ & 0.10 & 0.20 & 0.20 \\
\hline \multirow[t]{6}{*}{$6 m$} & $\mathrm{~B}$ & 98.40 & 92.90 & 92.90 \\
\hline & B-BR & 0.40 & 0.10 & 0.00 \\
\hline & $\mathrm{B}-\mathrm{W}$ & 0.80 & 0.10 & 0.20 \\
\hline & $\mathrm{BR}$ & 0.20 & 6.40 & 6.40 \\
\hline & BR-W & 0.00 & 0.10 & 0.10 \\
\hline & $\mathrm{W}$ & 0.10 & 0.30 & 0.30 \\
\hline \multirow[t]{6}{*}{$9 m$} & B & 97.60 & 95.50 & 95.40 \\
\hline & B-BR & 0.70 & 0.00 & 0.00 \\
\hline & B-W & 1.20 & 0.10 & 0.30 \\
\hline & $\mathrm{BR}$ & 0.40 & 3.90 & 4.00 \\
\hline & BR-W & 0.10 & 0.00 & 0.00 \\
\hline & $\mathrm{W}$ & 0.10 & 0.30 & 0.30 \\
\hline \multirow{6}{*}{$12 \mathrm{~m}$} & $\mathrm{~B}$ & 86.50 & 93.30 & 92.60 \\
\hline & B-BR & 3.60 & 0.30 & 0.50 \\
\hline & B-W & 6.60 & 0.90 & 1.30 \\
\hline & $\mathrm{BR}$ & 1.90 & 2.90 & 2.70 \\
\hline & BR-W & 0.30 & 0.10 & 0.30 \\
\hline & $\mathrm{W}$ & 1.00 & 2.40 & 2.60 \\
\hline \multirow[t]{6}{*}{$18 m$} & $\mathrm{~B}$ & 89.40 & 93.00 & 91.90 \\
\hline & B-BR & 2.90 & 0.50 & 0.90 \\
\hline & B-W & 4.70 & 0.80 & 0.90 \\
\hline & B-BR & 0.00 & 3.20 & 3.30 \\
\hline & $\mathrm{Br}$ & 1.80 & 0.10 & 0.40 \\
\hline & W & 1.20 & 2.30 & 2.60 \\
\hline \multirow[t]{6}{*}{$24 m$} & B & 86.60 & 90.30 & 87.80 \\
\hline & B-BR & 3.70 & 0.50 & 1.10 \\
\hline & B-W & 6.20 & 0.90 & 1.50 \\
\hline & BR-W & 0.00 & 5.80 & 6.30 \\
\hline & BR & 2.20 & 0.30 & 0.20 \\
\hline & W & 1.20 & 2.10 & 3.00 \\
\hline \multirow[t]{6}{*}{ Adult } & B & 81.20 & 92.00 & 90.30 \\
\hline & B-BR & 5.60 & 0.60 & 1.00 \\
\hline & B-W & 8.10 & 0.70 & 0.80 \\
\hline & BR & 3.00 & 4.10 & 4.20 \\
\hline & BR-W & 0.40 & 0.40 & 0.40 \\
\hline & $\mathrm{W}$ & 1.50 & 2.30 & 3.20 \\
\hline
\end{tabular}

Note: - $\mathrm{B}$ = black, $\mathrm{BR}$ = brown, $\mathrm{W}=$ white, $\mathrm{B}-\mathrm{BR}=$ =black-brown, $\mathrm{B}-\mathrm{W}=$ black-white, $\mathrm{BR}-\mathrm{W}=$ brown-white colour. 
Table.3 Mean and standard deviation of body measurements of Marwari goats

\begin{tabular}{|l|l|l|}
\hline Parameters & Mean & Std. Deviation \\
\hline Height & 57.00 & 13.549 \\
\hline Length & 51.35 & 11.787 \\
\hline Heart G & 61.64 & 16.672 \\
\hline ear length & 14.57 & 5.382 \\
\hline Horn & 6.44 & 3.898 \\
\hline
\end{tabular}

Table.4 Correlation between morphometric measurements of Marwari goats

\begin{tabular}{|l|l|l|l|l|l|l|}
\hline parameters & height & length & Heart G & Ear length & Horn & Body coat \\
\hline Height & 1 & $.830^{* *}$ & $.856^{* *}$ & $.632^{* *}$ & $.568^{* *}$ & $.116^{* *}$ \\
\hline Length & & 1 & $.773^{* *}$ & $.584^{* *}$ & $.579^{* *}$ & $.102^{* *}$ \\
\hline Heart G & & & 1 & $.639^{* *}$ & $.554^{* *}$ & $.089^{* *}$ \\
\hline $\begin{array}{l}\text { Ear } \\
\text { length }\end{array}$ & & & & 1 & $.489^{* *}$ & $.113^{* *}$ \\
\hline Horn & & & & & 1 & $.077^{* *}$ \\
\hline $\begin{array}{l}\text { Body } \\
\text { coat }\end{array}$ & & & & & & 1 \\
\hline
\end{tabular}

Note:**Correlation is statistically significant at the $0.01 \%$ level (2-tailed).

Fig.1 Body coat colour of Marwari goat

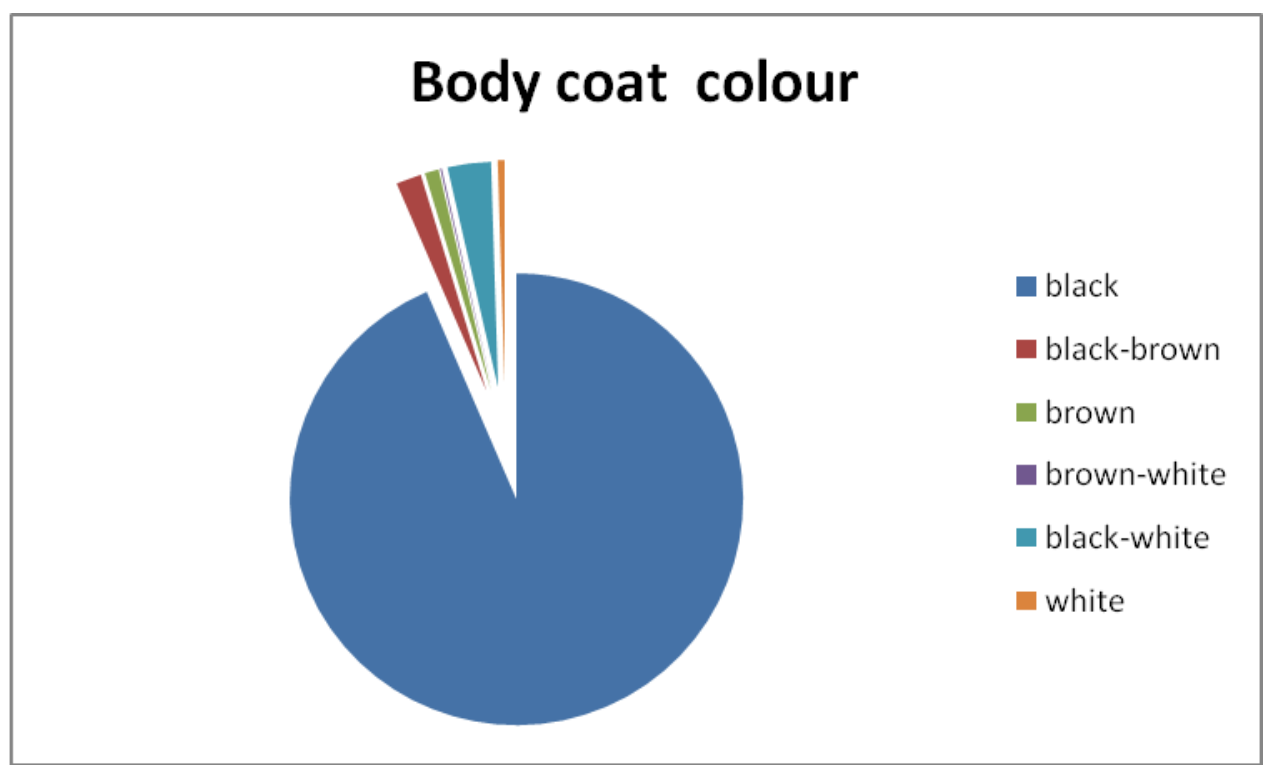

\section{Ear length}

Ear length was reported as $16.01 \pm 0.06 \mathrm{~cm}$ for Marwari goats. The ear as a classifying feature can be described in terms of size and orientation. For example, ear length is used to identify the two goat breeds (Short-eared, medium eared and Long-eared) in the goat family. The Ear length of goats reported in literature as $\mathrm{Up}$ to $10 \mathrm{~cm}$ for Black Bengalgoats (Tudu et al., 2016), 13.73 \pm 0.10 $\mathrm{cm}$ for Chaugarkhagoats (Singh and Barwal,2007), $11.14 \pm 0.05 \mathrm{~cm}$ for Pallaiadu goats (Ravimurugan et al., 2009), $16.28 \mathrm{~cm}$ 
(Deokar et al., 2007) and 17.29 $\pm 0.19 \mathrm{~cm}$ (Verma et al., 2010) for Sangamneri goats, $17.09 \pm 1.25 \mathrm{~cm}$ for Surti goats (Dixit et al., 2013).

In conclusion, the data pertaining to various morphological traits had analyzed by IBM SPPS software to study the colours of body coat, Muzzle and ear colour. The predominant colour seen in all the animals was black followed by an admixture of black, brown and white. In present study estimated that out of total animals 10 per cent of animals were having beard and 9.4 per cent animals having wattles. Beard and wattles observed in both sex. The effect of coat colour were estimated as highly significant $(\mathrm{P} \leq 0.01)$ on all ages group animals. Correlation between height and length 0.830 , height and heart girth 0.0856 , height and ear length 0.632 , height and horn length 0.568 , height and coat colour 0.116 , length and heart girth 0.773 , length and ear length 0.584 , length and horn length 0.579 . length and coat colour 0.102 , heat girth and ear length 0.639, heart girth and horn length 0.554, heart girth and coat colour 0.089 , ear length and horn length 0.489 , ear length and coat colour 0.113 , horn length and coat colour 0.077.Marwari goat breed body coat colour predominantly seen black colour which indicate that black body coat colour were more adaptable for hot climate.

\section{Acknowledgements}

The authors are thankful to the ViceChancellor, Rajasthan University of Veterinary and Animal Sciences and Principal Investigator, AICRP on Marwari goats for providing all kind of facilities and other information for this study.

\section{References}

Anonymous, 2012.19 ${ }^{\text {th }}$ Livestock Census. Department of Animal Husbandry,
Dairying and Fisheries, Government of India.

Anonymous, 2018. National Bureau of Animal Genetic Resources (NBAGR), Karnal, Haryana, India.www. nbagr.res.in.

Cena, K. 1966. Observations on the absorption of solar radiation in cows and horses of various colours. ActaAgrisilvri. Sci. Zootech., 6: 93-138.

Deokar, D.K., Lawar, V.S., Pawar, B.K. and Andhale, R.R. 2007. Breed characteristics of Sangamneri goat. Ind.J. Small Rumin., 13(2): 213-215.

Deshpande,S.B., Desai, P.M., Kharadi, V.B. and SabaparaG.P. 2009. Phenotypic and performance characteristics of Surtigoats. Ind. J. Small Rumin., 15(1): 108-112.

Dixit, S.P., Aggarwal, R.A.K., Dangi, P.S., Verma, N.K., Vyas, M.K., Rana, J., Sharma, A., Kharadi, V.B., Sabapara, G.P. and Deshpande, S.B. 2013.Phenotypic characteristics, management, performance and genetic variability in Surti breed of goat.Ind.J. Anim. Sci., 83(4): 423-427.

Hutchinson,J.C.D. and Brown, G.B. 1969. Penetration of cattle coats by radiation. J. Appl. Physiol.,26: 454-464.

Kharkar, K., Kuralkar, S.V., Kuralkar, P., Bankar, P.S., Chopade M.M. and Hadole, K.A. 2014. Factors affecting body weight and morphometric characters of Berarigoats.Ind. J. Small Rumin.,20(1): 12-15.

Mandakmale, S.D., Mane S.H. and Kankhare,D.H. 2016. Morphological characterization of Kathewadi goat breed (unexplored) of Khandesh region of Maharashtra. Inter. Res. J. Multidisciplinary Studies.2(2): 201.

Pathodiya, O.P., Gurjar, M.L., Sharma, M.C. and Khadda, B.S. 2004. Studies on birth weight and morphometry of Sirohi kids in farmers field. Ind. J. Small Rumin., 10(1): 74-76. 
Patro, P.C. and Mishra. 1987. Performance ofGanjam breed of goats under field condition in Orissa. Ind. J. Anim. Prod. Management.3: 40-43.

Ravimurugan, T., Devendran, P., Cauveri, D. and Balachandran, S., (2009). Performance of indigenous goat (PallaiAdu) under field conditions. Tamilnadu J. Vet. Anim. Sci., 5(5): 203207.

Rohilla, P.P., Patel, A.K. 2003.Marwarigoat breed of Rajasthan.Ind.J. Anim. Sci., 73(6): 705-709.

Rout, P.K., Singh, M.K., Mandal, A. and Roy, R. 2002. Annual Report:AIRCP on Goat Improvement (Jamunapari), Animal Genetics and Breeding Division, CIRG, Makhdoom, Farah, Mathura (UP).

Shankarnarayan, K.A., Bohra, H.C. and Ghosh, P.K. 1985. The Goat: An appropriate animal for arid and semiarid regions. Econo.Political Weekly.20: 1965-1972.

Singh, S.K. and Rout, P.K. 2001. Annual Report of AICRP on Goat Improvement (Barbari), CIRG, Makhdoom ,Mathura.

Singh, C.V. and Barwal, R.S. 2007. Chaugarkha goat-a unique strain of goat in Central Himalayan ecosystem. Ind. J. Small Rumin., 13(1): 61-64.

Singh, M.K., Rai, B., Singh, S.K. and Singh, N.P. 2007. Morphological and physical attributes of Zalawadi goats. Indian Journal of Animal Sciences (India), 77: 1334-1337.

Singh,M.K., Rai, B. and Singh, N.P. 2009. Environmental and genetic effects on growth traits in Jamunapari kids. Ind.J. Anim. Sci., 79(6): 582-586.

Thiruvenkadan, A.K., Panneerselvam, S. and Kandasamy, N. (2000). Distribution characteristics and production performance of Kanni Adugoats of Tamilnadu.Ind.J. Anim. Sci., 70(7): 723727.

Tudu, N.K., Pyne, S.K. and Ghosh, N., (2016). Characterization of three colour varieties of Bengal Goats.Inter. J. Sci. Environ.Technol.,5 (5): 3332 - 3338.

Verma, N.K., Dixit, S.P., Dangi, P.S., Aggarwal, R.A.K., Kumar, S. and Joshi, B.K. 2009.Malabarigoats: Characterization, management, performance and genetic variability. Ind. J. Anim. Sci., 79 (8): 813-818.

Verma, N.K., Dixit, S.P., Aggarwal, R.A.K., Dangi, P.S. and Joshi, B.K.2010.Phenotypic and genetic characterization of Sangamneri goat breed.Ind. J. Anim. Sci., 80(11): 11091114.

Verma, N.K., Aggarwal, R.A.K., Dixit, S.P., Kawatikar, V.S., Dangi, P.S., Kaur, N., Mishra, P. and Joshi, B.K. 2012.KonkanKanyal-Characters and performance of a newly discovered goat germplasm of Maharashtra.Ind. J. Anim. Sci., 82(9): 1079.

Verma, N.K., Mishra, P., Aggarwal, R.A.K., Dixit, S.P., Dangi, P.S. and Dash, S.K. 2015.Characterization, performance and genetic diversity among goats of Odisha.Ind.J. Anim. Sci. 85(2): 165171.

\section{How to cite this article:}

Hemlata Chouhan, Gyan Chand Gahlot, Vijay Kumar Agrawal and Sunita Meena. 2020. Phenotypic Characterization of Marwari Goats under Field Conditions. Int.J.Curr.Microbiol.App.Sci. 9(06): 1868-1876. doi: https://doi.org/10.20546/ijcmas.2020.906.232 